\title{
EMPRÉSTIMOS PÚBLICOS E A SUA NATUREZA JURÍDICA
}

\author{
Sérgio Assoni Filho \\ Mestre e Doutorando em Direito Econômico- \\ Financeiro pela Faculdade de Direito da \\ Universidade de São Paulo.
}

\begin{abstract}
Resumo:
Neste trabalho, a partir dos elementos constitutivos do crédito público e de expressões que com ele estabelecem uma correlação, bem como considerando a evolução histórica e a atual utilização dos empréstimos públicos, o autor procura determinar a natureza jurídica dos empréstimos públicos, caminhando pelos meandros das correntes doutrinárias nacionais e estrangeiras mais abalizadas no tocante ao tema.
\end{abstract}

Abstract:

In this work, from the constituent elements of the public credit and of expressions that with it establish a correlation, as well as considering the historical evolution and the current use of the public loans, the author looks for to determine the legal nature of the public loans, dealing with national and foreign doctrinal chains to the subject.

Unitermos: crédito público; empréstimos públicos; natureza jurídica dos empréstimos públicos.

Keywords: public credit; public loans; legal nature of the public loans.

1. O Crédito Público: Aspectos Gerais.

1. I. O Conceito de Crédito e seus Elementos Constitutivos.

Segundo Oría, "crédito significa etimologicamente crer ou ter confiança" ' pois desde as primeiras versões e interpretações do latim, no século XVI, as palavras credo, crediti e creditum eram traduzidas por crer, confiar a outros ou emprestar crendo, ou seja, com fé na moral do tomador do empréstimo.

$\mathrm{Na}$ opinião do autor essa concepção vem se mantendo, uma vez que crédito seria um termo ligado à idéia de confiança ou fé na conduta de uma pessoa, isto é, em sua acepção geral e mais permanente, a palavra crédito estaria relacionada "com 
duas formas de crença: a confiança ou fé na moral de uma pessoa disposta a cumprir com os seus deveres e obrigações, e a crença de que poderá cumpri-los, por dispor de meios econômicos" 2

A lição de Say é clara no sentido de que o crédito. tanto o público quanto o privado, repousaria sobre a confiança dos prestamistas e sobre a existência de capitais disponíveis. Sendo esses elementos os dois termos do crédito, desde um irrisório empréstimo feito de um particular para outro particular, até o mais considerável empréstimo contraído pelo Governo de um pais, pois a base dessas operações seria a mesma, ainda que destoantes na forma e na proporção. Conclui dizendo que "não há crédito quando não há nem confiança e nem capitais, assim como quando há capitais sem confiança ou confiança sem capitais" 3

Como assevera Arruda, "o crédito pressupõe uma rclação fundada na confiança que o fornecedor do capital deposita no devedor. em virtude do conhecimento da situação econômica deste, Esse conhecimento se opera por meio da atividade econômica empreendida pelo devedor, não só considerando o estágio de evolução de tal atividade econômica, mas também a forma de conduzi-la.

Por sua vez, Leroy Beaulieu define o crédito como:

a possihilidade de proporcionar-se o gozo ou a disposição de um capital estranho, obtido livremente do verdadeiro proprietário; seja mediante a promessa de reembolso futuro nos prazos convencionados pelas partes; seja mediante uma remuneração do tomador ao prestamista, geralmente denominada juros: seja, por último, mediant' a adoção concorrente de ambas soluções. ${ }^{5}$

Ao lado dos elementos confiança e existência de capital, para que se efetive uma operação de cunho creditício, necessariamente estará presente o elemento

2. Ibid., p. 07.

3. SAY, Léon. Dictionnaire des finances. Paris: Berger-Lcvrault. 1889. v. I. p. 1335.

4. ARRUDA, João Paulo de. Aspectos do Capital Financeiro. São Paulu: Livraria Martins, 1942. p. 48.

5. LEROY BEAUlIEU, Paul. Science des Finances. Paris: Guillaumin. 1899. v. 2. p. 203. 
tempo, uma vez que o crédito implica a troca de um bem ou valor no presente por uma promessa de riqueza futura que, aliás, será a responsável pelo reembolso do que foi emprestado e pelo pagamento dos juros ou outros benefícios oferecidos aos prestamistas.

No dizer de COSSÉ, tomar emprestado é "antecipar-se sobre o futuro, é gozar antecipadamente o futuro" ${ }^{6}$ Pois, para ele:

tomado no sentido geral da palavra, o empréstimo é um ato pelo qual um dos contratantes coloca à disposição do outro capitais ou valores dos quais ele si depreende para lhe deixar ao seu gozo ou uso temporário, sob certas condições de remuneração do serviço e de garantias assegurando o seu reembolso no prazo de expiração convencionado. ${ }^{7}$

As colocações até aqui feitas são amplas e aplicam-se ao crédito de uma forma genérica, abrangendo tanto a idéia de crédito público quanto a de crédito privado. pois essa diferenciação, em nosso entendimento, é bastante sensivel e centrada essencialmente na nutureza do tomador do empréstimo, bem como na finalidade por ele encampada no momento em que recorre à operação de crédito, como procuraremos demonstrar mais tarde, ao analisarmos a natureza juridica do empréstimo público.

Até porque, quando o tomador for um ente público, a operação de crédito deverá ter um interesse público envolvido. isto é. deverá visar ao alcance de uma finalidade que seja socialmente relevante. enquanto, sendo o tomador um particular, os interesses envolvidos na operação de crédito serão, ao menos substancialmente, privados.

Tal é a sensivel diferença entre a operação de crédito pública e a operação de crédito privada que Geraldo Ataliba, um dos maiores estudiosos do regime jurídico dos empréstimos públicos. salientou:

6. COSSÉ, Ėmile. La Dette Publique et les Droits de l'État. Paris: Arthur Rousseau, 1884. p. 26.

7. Ibid., p. 25 . 
as relações jurídicas de direito público e privado, que se reunam sob a designação genérica de empréstimo, são revestidas das mesmus qualidades essenciais, de modo que ao direito público, e em particular o direito financeiro, são extensiveis os principios informadores das figuras obrigacionais elaboradas e desenvolvidas pela doutrina privatista, evidentemente adaptadas às peculiaridades do créditu público. ${ }^{8}$

Com base no crédito ou confiança de que dispõem o Estado ou as pessoas jurídicas de direito público interno que, em última análise, representam não só sua presença. mas também trazem consigo aquela presunção de perenidade e solvência que Ihe são próprias, é que se torna facilitada a aquisição dos recursos ou bens de que necessitam perante os seus proprietários originários, sejam eles capitalistas investidores ou meros cidadãos poupadores de suas economias.

Os fatores de convencimento dos prestamistas por parte do Estado vêm bem elucidados na lição secular de Cossa, quando ele afirma que o crédito público como faculdade de contrair débitos em condições favoráveis dependeria, em relação aos prestamistas, de circunstâncias que influissem sobre a vontade e sobre a possibilidade de o Estado cumprir com as suas obrigações assumidas. Afirmando que isso apenas se mostraria possível de acordo com "a benevolência do ordenamento político e administrativo do Estado, bem como das condições financeiras, do sistema de tributos, das cifras dos débitos anteriores e, finalmente, da condição econômica do Estado. isto é, do estado da riqueza nacional"

8. ATALIBA, Geraldu. Empréstimos Públicos e seu Regime Juridico. São Paulo: RT, 1973. p. 10-11. 9. COSSA. Luigi. Primi Flementi di Scienza delle Finanze. $9^{9}$ ed. Milano: Ulrico Hoepli, 1905. p. 181. 


\subsection{Crédito Público e Expressões Correlatas.}

Como mencionava Elpídio Figueiredo, há quase um século:

todos os paises procuram, por meio do empréstimo, que é a conseqüência natural do crédito, o recurso preciso para a realização dos melhoramentos exigidos pelo progresso moral e material de uma sociedade que acompanha os movimentos du civilização moderna. ${ }^{10}$

Assim sendo, havendo crédito público poderá o Estado recorrer a um empréstimo público junto aos capitalistas e poupadores, a fìm de prover suas necessidades de caixa ou de investimento, e dessa operação de crédito concretizada é que advirá a divida pública, em nome do atingimento dos interesses públicos, ou seja, de uma finalidade socialmente relevante, que em realidade é a responsável pela legitimidade de tal operação.

Apoiados na lição de Villegas, podemos então dizer que:

o crédito público é a aptidão politica, econômica, juridica e moral de um Estado para obter dinheiro ou bens em empréstimo; e que o empréstimo público é a operação de crédito concreta mediante a qual o Estado obtèm tal dinheiro ou bens; e a divida púhlica consiste na obrigação que contrai o Estado com os prestamistas como conseqüencia do empréstimo efetuado. "

Ressaltando que a forma com que o Estado lida com sua divida pública c o rigoroso adimplemento do que foi convencionado é um dos maiores indicadores da sua saúde financeira, bem como de seu crédito.

10. FIGUFIREDO, Elpidio. Principios Elementares da Ciência das Finanças. Recife: Diário de Pernambuco, 1909. p. 179.

II. VILLEGAS, Héctor B. Curso de Finanzas, Derecho Financiero y Tributario. Buenos Aires: Dipalma, 1972. p. 343. 
Tanto é assim que o enfático De Plácido e Silva leciona ser a divida pública "a obrigação a que não pode faltar o Governo, sem quebra da dignidade constitucional e do próprio crédito, que deve ser conservado a bem do País" 12

Entretanto, a operação de crédito efetivada será "patrimonialmente neutra" 13 nada sendo acrescido de forma absoluta aos cofres públicos, pois tudo aquilo que for angariado pelo Tesouro. sob a forma de empréstimo, o será de forma provisória e transitória, uma vez que deverá haver a restituição dos valores recebidos nos prazos fixados e na forma convencionada.

Como ensina Régis de Oliveira, todo e qualquer recurso que passe a Cazer parte dos cofres públicos, seja a que título for, denomina-se entrada, e essas entradas classificam-se, respectivamente, conforme sejam definitivas ou provisórias, em receitas e ingressos. De modo que, "não há ingresso definitivo" 14

Por essa mesma razão o notável Baleciro afirma serem os cmpréstimos meros ingressos ou entradas de caixa, não se incluindo entre as receitas propriamente ditas, uma vez que "não criam valores positivos para o patrimônio público, já que a cada soma recebida no ativo do Tesouro, a título de empréstimo. corresponde um lançamento no passivo contrabalançando-o" 15

Nesse sentido, também o mestre português Teixeira Ribeiro afirma que os recursos advindos de empréstimos públicos, ou seja, da utilização do crédito público, não aumentam o patrimônio do Estado, e os denomina de "receitas nãoefetivas" 16

12. DE PLÁCIDO E SILVA, Oscar José. Noções de Finanças e Dirciı Fiscal. 3. ed. Curitiba: Guaira, sem data. p. 115.

13. Cf. BASTOS, Celso Ribeiro. ('urso de Direito Financeiro e de Direito Trihutário. 7. ed. São Paulo: Saraiva. 1999. p. 56.

14. OLIVEIRA. Régis Fernandes de e HORVATH, Estevão. Mamual de Direito Financeiro. 4. ed. São Paulo: RT, 2001. p. 33-34.

15. BALEEIRO. Aliomar. Uma Introdução à Ciência das Finanças. 14. ed., atualizada por Flávio Bauer Novelli. Rio de Janeiro: Forense, 1984. p. 431.

16. TEIXEIRA RIBriRO. José Joaquim. Lições de Finanças Públicas. 5. ed. Coimbra: Coimbra Ed, 1997. p. 185. 


\subsection{Breve Histórico dos Empréstimos Públicos.}

Embora não haja um fato histórico que indique com precisão o início da utilização dos empréstimos públicos, acredita-se que o seu emprego remonte a vários séculos anteriores à era cristã ${ }^{17}$ uma vez que existem registros desse período que fazem referência a negócios com as características de um empréstimo público, e que eram firmados por imperadores. senadores e outros homens públicos dotados de notoriedade. $^{18}$

Naquela época, diferentemente de hoje, em que os empréstimos públicos são legitimados pelo atendimento das necessidades públicas, ou seja, são voltados à consecução de uma finalidade pública, a sua ocorrência destinava-se ao atendimento das necessidades e vontades pessoais do governante, que, aliás, tinha em sua própria pessoa a representação do Estado.

Nesses tempos em que o rei era considerado o próprio Estado. os empréstimos tomados por ele assumiam a característica de uma obrigação de cunho pessoal, sem qualquer ligação direta com o Estado. assim como não era transmitida necessariamente aos seus sucessores, visto que estes últimos poderiam repudiar o que havia sido acordado por aquele, muitas vezes, com o apoio da opinião pública.

Devido aos enormes riscos que tal negociação engendrava em relação aos prestamistas, o recurso ao expediente do empréstimo público pouco se desenvolveu na Antigüidade.

Até mesmo porque, em decorrência do enorme risco de inadimplemento, quando os prestamistas concediam o empréstimo, as garantias exigidas cram substanciais e havia o pagamento de juros muito elevados.

17. Rogério de Menezes Corigliano fala do surgimento dos empréstimos públicos por volta do terceiro milênio antes de Cristo (Empréstimos Públicos. São Paulo: FDUSP - Disscrtação de Mestrado. 2003. p. 26).

18. Aliomar Baleeiro apresenta, como resultado de uma refinada pesquisa histórica, vários exemplos ilustrativos. como: Xenofonte refere-se a empréstimos tomados por Atenas para a aquisição de barcos de gucrra; o empréstimo tomado por Cartago para pagar dividas de guerra; as cartas de Cícero a Ático, mencionando os impréstimos concedidos por banqueiros aos governantes subjugados pelu império romano; os negócios usurários realizados por César. Pompeu e Brutus a despeito da existência da lei Gabinia (67 a. C.), que proibia essa prática. (Uma Introdução..., p. 432-433). 
A Idade Média também não se apresentou propícia ao desenvolvimento dos empréstimos públicos, uma vez que eles ainda se revestiam do caráter de obrigação pessoal do governante e geralmente eram destinados ao financiamento das guerras.

Além disso, a produção não gerava excedentes que pudessem ser empregados nos referidos empréstimos e o sistema financeiro existente ainda era muito rudimentar, sem falar na doutrina religiosa e na concepção moral dominantes na época, que condenavam a prática de negociações usurárias.

Com o fim do sistema de produção feudal houve a evolução do chamado Estado Patrimonial, em que as finanças do rei eram confundidas com as finanças públicas, para o chamado Estado Fiscal, ${ }^{19}$ pois, com o advento do capitalismo, muda completamente a ideologia financeira até então existente, com a nítida separação dos bens públicos daqueles pertencentes aos governantes, e há uma gradual ampliação da atuação estatal, a fím de garantir não-só a segurança dos cidadãos (État Gendarme), mas também a prestação de serviços públicos e o cumprimento de um papel de caráter social (Welfare State), por meio de investimentos em saúde. educação, melhor distribuição de rendas etc.

Essas novas funções assumidas pelo Estado o obrigaram a buscar novas fontes de recursos, como os meios materiais indispensáveis ao atingimento desses objetivos, passando a incrementar o seu sistema tributário e a melhorar o gerenciamento de suas despesas e receitas, além de, eventualmente, recorrer aos empréstimos públicos.

$\mathrm{Na}$ Europa do final do século XVIIl e início do século XIX, em particular na Inglaterra, já é possível notar um significativo desenvolvimento na utilização dos empréstimos públicos, embora ainda recaísse sobre eles o estigma de processo financeiro maléfico ${ }^{20}$ e transferidor de encargos excessivos das gerações

19. Cf. LOBO TORRES, Ricardo. Curso de Direito Financeiro e Tributário. 8. ed. Rio de Janeiro: Renovar, 2001 . p. 06-08.

20. Aliomar Baleeiro destaca que, nos séculos XVII e XVIII, pensadores franceses como Montesquieu, Colbert, Saint-Simon e Quesnay, e pensadores ingleses, como David Hume e Adam Smith, declaravam serem os empréstimos públicos perniciosos e dignos de repulsa, uma vez que provocariam a ruina das nações, pois estimulariam o espirito bulicoso dos governantes e os conduziriam à aventuras nefastas, sem falar no afastamento das aplicações produtivas na agricultura. no comércio e na indústria, aniquilando os recursos em despusas estéreis de consumo e formando uma classe parasitária de pessoas improdutivas, que viveriam às custas dos juros, sem trabalharem ou assumirem qualquer risco empresarial (I'ma Introdução..., p. 435). 


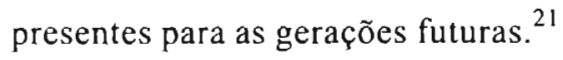

Após décadas de acaloradas discussões, com pareceres contraditórios dos especialistas na matéria, ${ }^{22}$ uma maior aceitação do recurso aos empréstimos públicos se fez presente no século XX, mais especificamente a partir de 1930, por influência das idéias de John Maynard Keynes, que preconizava ser o endividamento público um instrumento de intervenção do Estado na economia para a manutenção do pleno emprego. $^{23}$

Tais idéias ganharam fôlego especialmente após a Segunda Guerra Mundial, pois, com o agigantamento do Estado, resultante da sua evolução do Estado Policia para o Estado Providência, os recursos disponiveis não eram suficientes à consecução dos fins sociais e ao atendimento das necessidades públicas, e a utilização dos empréstimos públicos passou a ser encarada como uma alternativa viável, mediante a qual o Estado poderia angariar os referidos recursos e cumprir com o seu papel social.

Assim sendo, a utilização dos empréstimos públicos passou a estar desvinculada da ocorrência de situações extraordinárias, tais como calamidades públicas ou guerras, passando a ser uma mera forma de obtenção de recursos assim como o é a tributação. ou seja, o uso do crédito público pelos Governos passou a ser uma decisão político-econômica muito comum.

Somente a partir de 1970, quando os paises passaram por graves crises financeiras e orçamentárias, em parte, devido ao abuso na utilização dos empréstimos públicos sem um adequado planejamento de médio e longo prazos, com o conseqüente

21. Sobre usse aspecto de caráter econômico que foge aos objetivos do presente istudo, vide a seguinte obra. de Richard A. Musgrave: Teoria das Finanças Públicas: um cstudo da econoınia governamental. trad. Auriphebo Berrance Simões. São Paulo: Atlas, 1973. v. 2.

22. Como se pode notar das seguintes opiniões doutrinárias:

Para Ėmile Cossé: "Os empréstimos são perigosos expedientes, que somente se justificam quando a necessidade se impõe. Todo empréstimo que nâo é inevitávcl é um ato de loucura" (Op. cit., p. 386).

Já para Edmond Chassery: "O crédito, corretamente e sabiamente manipulado, é um maravilhoso instrumento que permite criar riquezas" (Les illusions de l'Amérique en matière de Crédit. Paris: Libranie Technique et Economique. sem data, p. 295).

Ainda, para Carlos José de Assis Ribeiro: "A conveniência do empréstimo encontra-seno destino a que se der ao seu produto. tudo dependendo de esquemas e planejamentos, previamente elaborados, em função dos fatores reprodutividade, interesse público e interesse social" (Financiamentos de Obras Públicas. Rio de Janeiro: Edições Financeiras, 1956. p. 105-106).

23. Para Ricardo Lobo Torres, a aceitação das idéias de Keynes foi um fenômeno mundial, atingindo tanto paises ricos como os Estados Unidos da América quanto países pobres como o Brasil. de modo que houve uma brutal elevação no volume de empréstimos públicos, e a execução deficitária dos orłamuntos públicos tornou-se uma constante (Op. cit., pp.193-194). 
descontrole do endividamento, é que passou a haver novamente uma ccrta rejeição à idéia de recorrer a tal expediente como meio eficaz de aquisição de recursos financeiros.

Um exemplo disso é o Brasil, pois, como país politicamente independente, teve sua origem ligada à realização dos empréstimos públicos, visto que sua independência da metrópole portuguesa ocorreu mediante a assinatura pelo príncipe regente de um Decreto, em 1822, que autorizava o chamado "empréstimo de independência", de modo que o país iniciou sua vida política atrelada ao convívio com a dívida pública, que, aliás, só fez crescer até os dias de hoje, com a constante aquisição de empréstimos públicos internos e externos.

Apesar dessa longa tradição brasileira de tolerância com o endividamento público, a partir da Constituição Federal. de 1967, com a redação que lhe deu a Emenda ('onstitucional n. 1, de 1969, o regime jurídico dos empréstimos públicos passou a ser bem mais rígido, ${ }^{24} \mathrm{e}$ tal tendência foi mantida pela Constituição Federal vigente.

Ao lado da rigidez constitucional, no âmbito infraconstitucional as finanças públicas passaram a ter destaque, principalmente no que tange ao controle orçamentário e do endividamento público, particularmente com a edição da lei federal n. 4.320. de 17 de março 1964 e, mais recentemente, da lei complementar n. 101 , de 05 de maio de 2000, que ficou conhecida como a lei de responsabilidade fiscal.

Desse modo, o ordenamento jurídico brasileiro passou a perseguir de forma mais efetiva um maior equilíbrio fiscal e orçamentário, a fim de evitar os efcitos negativos de uma política governamental defícitária como, por exemplo, a erosão de seu crédito público junto aos investidores nacionais e estrangeiros.

Além disso, a postura do Governo brasileiro vai ao encontro dos anseios do Fundo Monetário Internacional (FMI) e do Banco Internacional de Reconstrução e Desenvolvimento (BIRD), também conhecido como Banco Mundial, que recomendam essas práticas como indicativas de uma boa gestão fiscal e dignas de concessão de crédito.

24. Assim se manifesta Geraldo Ataliba a respeito da Constituição de 1967, com Emenda n. I, de 1969, no que concernc ao regime jurídico dos empréstimos públicos: "Não podemos deixar de assinalar. inicialmente, o profundo contraste entre esta abundância de regras - e conseqüente rigidez do sistema atual - e a parcimônia que caracterizou o regime das Constituições de 1946 e as anteriores. Da mesma forma. simples inspeção visual enseja verificar a diferença quantitativa e qualitativa entre o nosso sistema e o de paises. mesmo federaçōes, de cultura próxima ou semelhante à nossa" (Empréstimos..., p. 30). 
Essas instituições financeiras internacionais foram criadas com a celebração da Convenção Internacional de Bretton Woods, em 22 de julho de 1944, da qual o Brasil é signatário, para funcionarem como verdadeiros entrepostos entre os países que dispõem e aqueles que necessitam de recursos.

O Brasil recorre aos empréstimos provenientes dessas instituições desde a época da construção de Brasília, o que resulta, desde aquela época, em sua enorme ingerência nas políticas nacionais de caráter macroeconômico.

\subsection{A Hodierna Utilização dos Empréstimos Públicos.}

$\mathrm{Na}$ atualidade. como ficou demonstrado em sua evolução histórica, o recurso aos empréstimos públicos passou a ser corriqueiro, deixando de estar vinculado àquela idéia de que ele seria um meio extraordinário de obtenção de ingresssos aos cofres públicos, como expediente do Estado. somente em casos de urgência, calamidade pública e beligerância ou sua iminência.

Até mesmo porque. com a ampliação da atuação estatal e seu intervencionismo crescente em quase todas as atividades humanas, outros recursos além daqueles advindos da exploração de seu próprio patrimônio e da tributação passaram a se constituir em uma necessidadc constante, não-só para que o Estado pudesse arcar com seus desacertos momentâneos de caixa e investimentos de utilidade pública, mas também para atender a uma crescente demanda social.

No dizer de Oría, "o Estado é cada dia mais, não-só a pessoa política. juridica e moral representutiva da coletividade, mas também o expoente da solidariedade social" 25

O empréstimo público deixou de ser um recurso extraordinário, como antes a ele se referiam os financistas clássicos, passando a ser considerado uma forma ordinária de ingresso, ou seja. um verdadeiro e natural recurso do Estado.

Como ensina Fonrouge. o empréstimo público se transformou em um recurso tão normal cuanto o imposto, sendo a escolha entre ambos uma simples questão de oportunidade. Portanto, fixou-se modernamente que $\cap$ empréstimo, 
“oportuna e racionalmente utilizado, pode constituir um instrumento de governo e não, como antes, um mero expediente de exceção para cobrir gastos" 26

Também o mestre italiano Morselli, já há mais de meio século, preconizava que os dois procedimentos, o do empréstimo e o do imposto extraordinário, e em especial, o imposto extraordinário de caráter patrimonial, tecnicamente não deixavam diferença, de modo que, também por isso, sobre a escolha por um ou por outro, mais do que nunca, "o interesse público do momento é que deveria decidir" 27

Por sua vez, Ferreiro Lapatza salienta que hoje em dia o empréstimo público é um recurso normal da Fazenda que não está ligado às circunstâncias extraordinárias, pois "o empréstimo, do ponto de vista do direito financeiro, não é mais que uma técnica para conseguir determinados fins. Uma regulação normativa da atividade do Estado dirigida a consegui-los" 28

Nesse sentido também. Baleeiro afirma que nos últimos séculos, na maioria dos paises, os empréstimos públicos vêm sendo considerados como "um processo normal e ordinário de suprimento dos cofres públicos" 29

2. A Natureza Jurídica dos Empréstimos Públicos.

Questão das mais debatidas na doutrina e que ainda não se esgotou é a que se refere à naturça jurídica dos empréstimos públicos, uma vez que a essência dessa obrigação assumida pelo Estado diante dos prestamistas dá margem à existência de interprctações divergentes.

Antes de nos posicionarmos, apresentaremos as duas correntes doutrinárias que em nosso entendimento mostram-se mais significativas, por conterem uma maior substância de argumentos e por terem um maior número de defensores $\mathrm{com}$ autoridade na matéria.

26. FONROUGE, Carlos M. G. Derecho Financiero. 3. ed. Buenos Airrs: Depalma, 1977. v. 2. p. 12-13.

27. MORSELL1, Emanuele. Compendio di Scienza delle Finanze. 21. ed. Padova: CFDAM. 1952. p. 305 e ss.

28. FERREIRO LAPATZA, José Juan. Curso de Derecho Financiero Espuñol. 19. ed. Madrid: Marcial Pons. 1997. p. 554.

29. Uina Introdução..., p. 431. 
A primeira corrente defende a idéia de que o empréstimo público é um ato unilateral de soberania do Estado, e tem como paladinos os memoráveis Drago, Fonrouge, Ingrosso e Sayagués Laso.

Já a segunda corrente, por sinal com um maior número de adeptos, compartilha o entendimento de que o empréstimo público é um contrato firmado pelo Estado com os prestamistas, assim o proclamam, dentre outros, os notáveis Trotabas, Jèze, Duverger e Ferreiro Lapatza.

\subsection{O Empréstimo Público como Ato Unilateral de Soberania.}

Dentre os que defendem a tese de ser o empréstimo público um ato de soberania, destaca-se Drago, pois foi um dos pioneiros a tratar da questão, e as suas idéias constituintes da conhecida "Doutrina Drago" serviram de ponto de partida para os demais doutrinadores que se filiaram a essa corrente.

Para Drago. o reconhecimento da dívida pública. bem como a sua liquidação. devem ser feitos pela nação sem o desprezo de seus direitos primordiais como entidade soberana que é. Até mesmo porque, os prestamistas sabem que o Estado é dotado de soberania e que é condição inerente à toda soberania a impossibilidade de obtenção de seu direito de crédito via execução forçada caso ele se torne inadimplente, pois o seu patrimônio é inalienável e, portanto, impenhorável. ${ }^{30}$

Prossegue ele afirmando que os títulos representativos da dívida pública de um Estado constituem uma classe ou categoria excepcional de obrigações que não podem ser confundidas com nenhuma outra, visto que tais títulos são emitidos em virtude do poder soberano do Estado, assim como a moeda, surgindo em decorrência de autorizações legislativas e não apresentando as características gerais dos contratos de direito privado, uma vez que, na sua opinião, não existe uma pessoa determinada a favor da qual se estabelecem obrigações, pois o pagamento dos títulos é prometido de forma indeterminada ao portador. O prestamista adquire os títulos representativos de seu crédito no mercado anônimo de capitais, sem qualquer formalidade ou relação com o governo devedor, diferentemente do adiantamento de dinheiro promovido por aquele nos contratos ordinários de mútuo. ${ }^{31}$

30. DRAGO, Luis Maria. Discursos y escrilos. Buenos Aires: El Ateneo, 1938. v. 2. p. 49-51. 31. Ibid., p. 100. 
Conclui dizendo que a dívida proveniente dos empréstimos públicos internos ou externos com emissão de bônus ou de títulos com determinados juros constitui a divida pública propriamente dita. ou divida nacional. e que a sua cobrança "não pode dar lugar à ações judiciais. porque esses bônus ou títulos saem de circulação assim como o papel moeda. e o seu serviço é atendido ou suspenso em virtude de atos de soberania. perfeitamente caracterizáveis como tais". 32

Por sua vez, Fonrouge é incisivo ao afirmar que considera inaceitável a posição contratualista, pois na sua opinião:

a obrigação derivada do empréstimo público nascc anteriormente e independentemente do consentimento dos subscritores, de modo que a aceitação tácita, por parte destes, das condições fixadas no documento emitido, não configura, nem aperfeiçoa e nem integra a obrigação assumida pelo Estado, que é exclusivamente unilateral, e uma vez não havendo contrato com o primeiro tomador, menos ainda haverá com os posteriores possuidores do título, que o adquiriram na Bolsa ou no mercado; e no caso dos títulos nominais o Estado se limita a estampar um nome na primeira vez, e no futuro somente toma nota das transcrições entre pessoas que lhe são estranhas, de forma que não seria possivel falar em acordo de vontades e nem de uma recíproca fixação de condições, pois os títulos são lançados no mercado e desde o mumento inicial adquirem individualidade própria, como coisas com um valor intrinseco nominal ou estabelecido pelo mercado, que comprometem o Estado ao cumprimento das condições fixadas, antes mesmo da subscrição, portanto, antes de qualquir ato de consentimento. ${ }^{33}$

32. Ibid.. p. 138-139.

33. Op. cil., p. 1027-1028. 
Arremata argumentando que as condições do cmpréstimo são estabelecidas mediante lei, que ¿̇ a expressão da soberania do Estado, scm que haja a possibilidade de a vontade dos particulares influírem a respeito, pois o processo formador da obrigação "nasce aperfeiçoado em virtude do ato legislativo de criação" 34

Note-se também que Fonrouge compartilha da opinião de Drago quanto à impossibilidade de execução forçada do Estado devedor do empréstimo diante de autoridade judicial. Frisando que essa solução não pode prevalecer "nem mesmo hipoteticamente", uma vez que não existe um tribunal competente para julgar um ato de soberania, pois a obrigação assumida pelo Estado repousaria pura e exclusivamente na confiança que ele inspira e que se traduz em seu prestigio nos mercados nacional e internacional, e as garantias de adimplemento oferecidas seriam inoperantes na prática, exatamente "pela falta de meios lícitos para torná-las efetivas" 35

Também Ingrosso filia-se a essa corrente, afirmando ser a dívida pública uma relação de direito público, cujas condições são estabelecidas mediante lei, que é a expressão da soberania estatal, de modo que a obrigação dela advinda apresenta-se unilateralmentc e não sob a forma contratual.

Em seu entendimento, portanto. com a existência de uma lei. que é a expressão da soberania do Estado, fixando as condições dessa relação de direito público, torna-se impossivel a colaboração da vontade de um dos sujeitos, no caso o prestamista, e "se não há sua contribuição para a formação do negócio. não existe contrato" 36

O mestre uruguaio Sayagués Laso também não admite a natureza contratual do empréstimo público. seja ele considerado de direito privado ou seja ele considerado de direito público. Salientando que tal relação obrigacional "tem características específicas que não permitem concebê-la como um contrato. tipificando uma obrigação autônoma unilateral com valor por si mesma, que pode ser utilizada de muitas maneiras e com finalidades diversas" 37

34. Ibid., p. 1028.

35. Ibid. cil., p. 1028.

36. INGROSSO, Gustavo. Istituizioni di Diritto Finanziario. Napoli: Jovene, 1954. p. 744 e ss.

37. SAYAGUÉS LASO, Enrique. Tratado de Derecho Administrativo. Montevideo, 1959. v. 2, p. $127-128$. 
2.2. O Empréstimo Público como Contrato.

A doutrina francesa em sua maioria é partidária da corrente contratualista, destacando-se as posições de Trotabas, Jèze « Duverger.

Para Trotabas, o emprístimo público tem uma origem legal, assim argumentando:

ele não pode ser emitido sem a intervenção do Poder Legislativo. Mas, o regime juridico que se estabelece entre o Estado tomador do empréstimo e o capitalista prestamista não é um regime legal, de direito objetivo. modificável a todo instante pela lei. A lei do empréstimo seria apenas a condição de exercicio do poder de tomar emprestado, que pertence ao Governo, e o uto juridico do empréstimo se realiza, em virtude do oferecimento que é feito pelo Ministro das Finanças conforme a demanda emanada dos subscritores: há um acordo de vontades criador de uma situação juridica, isto é, de natureza contratual. ${ }^{38}$

Enfaticamente ele ainda prossegue em seu raciocínio dizendo que todas as teorias que procuram estabelecer, sob o pretexto da soberania, ou da legitimidade de um regime, que os empréstimos públicos não são obrigatórios para o Estado. são juridicamente falsas. Na sua visão, essas teorias buscam em vão justificar em direito quão nocivos poderiam ser os procedimentos aos quais os Estados seriam constrangidos política ou economicamente a arcar com seus compromissos, mas ao mesmo tempo negligenciam que o descumprimento daquilo que foi previamente acertado é sempre condenável juridica e moralmente. Até mesmo porque, para ele. os empréstimos públicos são tão obrigatórios quanto os empréstimos privados, pois "o fato de o empréstimo público apresentar-se como um contrato de direito público não atenuaria este seu caráter obrigatório" 39

38. TROTABAS, Louis. Précis di Science et Législation Financières. 9. ed. Paris: Dalloz, 1947. p. 391. 39. Ibid. p. 391. 
Jèze também é explícito afirmando que, como procedimento jurídico. o empréstimo público é um contrato, um acordo de vontades, e é com base no crédito de que se aproveita o Estado que ele é adquirido junto aos prestamistas. Dizendo que:

como todos os contratos, quer sejam eles concluidos por particulares ou por agentes púhlicos, o empréstimo público dá lugar a situações jurídicas intangiveis. Os credores do patrimônio administrativo tomador do empréstimo adquirem um direito de crédito que os Governos e os agentes do Estado têm o dever juridico de respeitar, de modo que sob nenhum pretexto e por nenhum motivo deixarão de ser responsabilizados: as despesas do serviço da divida são obrigatórias. ${ }^{40}$

Por sua vez, Duverger inicia seu raciocinio comparando o empréstimo público ao imposto, dizendo que o imposto, como o próprio nome indica, é uma imposição ao contribuinte que ele tem que aceitar, tendo em vista que não pode recusar. Ao contrário. o empréstimo está baseado na concordância dos subscritores. uma ve $\angle$ que em condições normais ninguém é obrigado a subscrever o empréstimo, de modo que somente o subscrevem aqueles que assim quiserem. Portanto, "juridicamente o imposto é decidido por um ato unilateral do Estado, e o empréstimo é um contrato" 41

Prossegue em sua argumentação ressaltando que há, entretanto, uma importante diferença entre o empréstimo público e os empréstimos privados, uma vez que. entre os particulares, as condições do empréstimo compõem o objeto de uma discussão entre o prestamista e o tomador, visto que as cláusulas são debatidas e estabelecidas em comum acordo, de modo que haveria um contrato na sua forma tradicionalmente concebida.

No que concerne ao empréstimo público. a situação não seria a mesma, porque o Estado fixa sozinho, unilateralmente, as condições do empréstimo: taxas de juros, formas de emissão, datas de reembolso etc. O subscritor pode somente aceitar ou

40. JĖZ.E. Gaston. Cours de Science des Finances el de Législation Financière Française. 6. ed. Paris: Marcel Giard, 1922. p. 294.

41. DUVERGER, Maurice. Finunces Publiques. 8. ed. Paris: PUF, 1975. p. 135. 
recusar como um todo a subscrição, de maneira que se ele aceita, deverá se submeter a todas as cláusulas estabelecidas pelo Estado, uma vez que não poderá discutir com o Estado para obter condições mais favoráveis, devendo aderir às condições gerais estabelecidas para todos os prestamistas. Haveria assim uma uniformidade na situação jurídica dos subscritores do mesmo empréstimo, que ficaria distante da concepção tradicional do contrato. ${ }^{42}$

Diz ainda que "se o empréstimo do Estado é um contrato, é um contrato de natureza especial: um contrato de direito público, em quc o poder e a autoridade do Estado se munifestam por meio de uma moldura contratual. para fixar as cláusulas de forma unilateral" ${ }^{43}$

Conclui comentando que contratos desse tipo passaram a ser chamados de "contratos de adesão", pois apenas uma das partes fixa as cláusulas a que a outra deverá pura e simplesmente aderir. Entretanto. notou-se que esses contratos imperam mesmo em relação aos particulares, até porque a noção de contrato livremente debatido é muito mais teórica do que prática, pois muito freqüentemente haveria desigualdade de fato entre as partes presentes, o que sempre permitiria a uma delas fixar condições para a celebração do contrato. De modo que a diferençiação entre os contratos de empréstimos públicos e os contratos de empréstimos privados não teria muita importância prática. ${ }^{44}$

Entre os financistas espanhóis também predomina a simpatia à corrente contratualista, destacando-se Ferreiro Lapatza, que se aprofundou no estudo da natureza jurídica dos empréstimos públicos.

Segundo ele. os efeitos jurídicos da vontade do Estado de tomar emprestado, declarada por meio da emissão de títulos representativos da dívida pública, explicam-se recorrendo à figura da oferta de contrato. De modo que, na análise jurídica da divida pública, observa-se a diferença entre a manifestação da vontade do Estado dirigida a quem queira entregar uma soma de dinheiro em empréstimo (oferta de contrato) e a manifestação materializada da entrega e aceitação dessa soma, também

42. Ibid.. p. 135-136.

43. Ibid., p. 136.

44. Ibid.. p. 136. 
como declaração da vontade dos sujeitos que querem produzir um efeito jurídico, portanto, um contrato. ${ }^{45}$

Para ele, nem a indeterminação da pessoa com quem se vai contratar. no momento da emissão dos títulos da dívida pública, nem a fixação de condições por somente uma das partes invalidam a teoria contratual, pois nesses casos têm-se, respectivamente, a oferta de contrato feita ao público e o contrato de adesão.

Salientando ainda que a impossibilidade de execução forçada do patrimônio do Estado inadimplente não seria suficiente para negar a existência do caráter contratual, uma vez que a impossibilidade da execução forçada não implica a inexistência do contrato, citando a lição de Van Hecke, no sentido de que a insuficiência de uma sanção não implica a inexistência de uma regra. ${ }^{46}$

Em sua argumentação destaca, ao falar dos empréstimos públicos internos, que é conveniente fazer referência à distinção das três funções típicas do Estado, quais sejam: a executiva, a legislativa e a judicial.

Isso porque, na sua opinião, a contratação de um empréstimo público por parte do Estado é uma relação disciplinada pelo seu ordenamento jurídico interno. como em qualquer outro contrato privado. $O$ fato de o Estado poder anular os efeitos de tal contrato mediante uma lei (grifo nosso) não influiria em sua natureza jurídica, não o destipificaria como contrato, visto que a lei estaria fora e acima da relação contratual. Até mesmo porque, considera que a lei pode vir a modificar os efeitos de um contrato de direito público, tanto quanto pode modificar os efeitos de um contrato de direito privado.

Frisando lambém que é inválida a afirmação de que no caso dos empréstimos públicos é o Estado, ou seja, é o devedor, que modifica os efeitos do refurido contrato, pois uma vez observada aquela tripartição funcional descrita, o devedor é o Estado-Administração, e quem modificaria os efeitos do contrato mediante a lei seria o Estado-legislador.

Após tecer essa sua linha de raciocínio, enfatiza que na sua opinião o acordo de vontades existente entre o Estado tomador do empréstimo, que o solicitou e ao qual concorreu voluntariamente o prestamista, seria o gerador dos efeitos jurídicos

45. Op. cit., p. 550.

46. Ibid., p. 550 . 
advindos dessa relação obrigacional, de forma que, definitivamente, essa relação seria regida por um contrato. ${ }^{47}$

Ferreiro Lapatza vai ainda mais longe na análise da questão, ao questionar se tal contrato de empréstimo público. submetido pois ao ordenamento jurídico interno do Estado, obedeceria às regras de direito público (administrativo) ou às regras de direito privado (comum).

Ressaltando que o requisito indispensável para o entendimento de que esse conjunto de normas, regulador da relação contratual, seja de direito administrativo, é a presença do Estado-Administração na qualidade de parte, mas com sua atuação pautada pelo interesse público, como um verdadeiro ente público, e não como um particular qualquer que estivesse submetido às normas de Direito Privado. ${ }^{48}$

Prossegue afirmando que, a seu juízo, a atividade desenvolvida pelo Estado quando contrata um empréstimo público seria exercida como verdadeiro ente público, como verdadeiro Estado-Administração, uma vez que dotado estaria de poder de império. ou seja, sem se colocar em pé de igualdade com o particular, haja vista ter sido motivada a contratação pela defesa de um "interesse coletivo primário" como, por exemplo, o desenvolvimento dos serviços públicos. que é o próprio campo de atuação do Estado-Administração.

Daí a sua justificativa para a presença nesse tipo de contrato das ditas "cláusulas exorbitantes" que não-só poderiam beneficiar o Estado, mas também, em muitos casos, apresentarem-se mais favoráveis aos prestamistas do que as condições usuais de mercado, a fim de atraí-los à contratação, em última análise. procurando sempre o bem da coletividade.

Assim sendo, no seu modo de ver, o empréstimo público seria contraído pelo Estado como ente público propriamente dito, de modo que a relação contratual a que se daria vida encontraria seu regime jurídico nas normas de Direito Público ou de Direito Administrativo. ${ }^{49}$

Ferreiro Lapatza finaliza dizendo o seguinte:

47. Ibid., p. 551.

48. No que concerne à diferenciação entre os contratos celebrados pelo Estado-Administraçào, sob os regimes de direito público e de direito privado vide: MEIRELLES, Hely Lopes. Direito Administrativo Brasileiro. 22. ed. São Paulo: Malheiros, 1997, p. 194 e ss. e DI PIETRO. Maria Sylvia Lanella. Direito Administrativo. 6. ed. São Paulo: Atlas, 1996. p. 207 e ss.

49. Op. cit., p. 552. 
a divida pública refere-se a um contrato real, unilateral, de direito público, pela qual uma das partes, que pode ser um ente público ou privado, entrega a um ente público uma quantidade de dinheiro, comprometendo-se este último ao seu reembolso com juros, ou a pagar somente os juros, ou ainda a pagar um determinado montante durante um certo tempo. $^{50}$

Compartilha de seu entendimento o ilustre Sainz de Bujanda, ${ }^{51}$ que, aliás, faz reverência a essa gama de argumentos apresentados por Ferreiro Lapatza, como sendo os de maior substância na matéria dentre os doutrinadores espanhóis.

Também Pérez Royo afirma, quanto à natureza dos ingressos representativos da dívida pública. que tais ingressos "são obtidos com base em uma relação contratual, que no caso da divida interna deve ser considerado um contrato de direito público" 52

Ainda dentre os doutrinadores espanhóis, Carrera Raya leciona que "o Estado, enquanto Administração, fica subınetido às cundições contratuais do empréstimo público, e que em nada se debilita sua natureza contratual o fato de que, eventualmente, o Estado-legislador modifique aquela relação" 53

Elencando na seqüência uma série de características que, em sua dicção. destacariam que o regime jurídico do contrato de empréstimo público seria exclusivamente administrativo, uma $v e z$ que o ente público tomador do empréstimo ostentaria uma série de prerrogativas que o colocariam em uma posição de supremacia no seio do negócio contratual.

Expressamente refere-se a cinco dessas características. quais sejam:

50. Ibid., p. 552.

51. SAINZ DE BUJANDA, Fernando. Lecciones de Derecho Financiero. 7. ed. Madrid: Universidad Complutense, 1989. p. 405 ess.

52. PÉRE7. ROYO, Fernando. Derecho Financiero y Tribulario. 9. ed. Madrid: Civitas, 1999. p. 410.

53. CARRERA RAYA, Francisco José. Manual de Derecho Financiero. Madrid: Tecnos, 1994. v. 01. p. 153. 
a) o serviço público: diz que seria coerente deduzir que o empréstimo público tem a natureza de contrato administrativo, uma vez que os fundos obtidos dessa maneira não seriam mais que simples meios para atender a atividade gestora normal dos entes públicos, ou seja, esse contrato seria utilizado como um dos instrumentos de execução dos serviços públicos que o Estado tem para si encomendados.

b) as prerrogativas do poder público: fala da existência no regime jurídico dos empréstimos públicos de um conjunto de prerrogativas, que existiriam unicamente em favor do ente público tomador do empréstimo, e que teriam como razão de fundo justificadora a relação imediata do contrato de empréstimo público com o atendimento das necessidades públicas. o que indicaria assim sua inclusão na categoria dos contratos administrativos.

c) a posição desigual das partes no contrato: afirma que no contrato de empréstimo público as partes ocupariam uma posição desigual como conseqüência da existência das prerrogativas em favor do ente público tomador do empréstimo, até mesmo porque ele representaria o interesse coletivo e não um mero interesse particular.

d) a adesão: fala que o Estado-Administração impõe condições de contratação via normas ou cláusulas. aos quais caberia ao prestamista somente aceitar a oferta na forma proposta ou simplesmente recusá-la sem qualquer possibilidade de discuti-la. Assim sendo, os prestamistas deveriam aderir a tais condições fixadas pelo ente público tomador do empréstimo ou nem existiria o vinculo contratual entrc eles.

e) a jurisdição: menciona ainda que nos países que adotam o contencioso administrativo, a competência da jurisdição administrativa deveria ser observada nas questões conflitantes que surgissem com relação ao contrato de empréstimo público, tornando-se assim clara a indicação de sua qualificação jurídica como de um contrato de cunho administrativo. ${ }^{54}$

A título de conclusão, diz ele que "o empréstimo público é um contrato administrativo" 55 em que o Estado-Administração assume o compromisso de devolver 
o capital emprestado mais os juros, ou a pagar somente os juros ou uma quantidade de dinheiro durante certo tempo ao prestamista.

A corrente contratualista também tem um maior número de adeptos entre os financistas da Amirica do Sul, e aqui apresentaremos as teses de alguns deles, que se destacaram.

Iniciamos com De Juano, que preconiza ser o empréstimo público "um contrato de direito público regido essencialmente por normas constitucionais e administrativas, especialmente naqueles dispositivos que se referem ao crédito público" 56

Entretanto, ele coloca em relevo que tal regime de direito público não poderia dar margem a alguma arbitrariedade por parte do Estado, visto que caberia a este devolver o que foi emprestado conforme as bases previstas quando da emissão do empréstimo. Até porque, a operação seria feita èm nome do interesse público. e comprometendo o bom nome e a honra do Estado, de modo que o descumprimento do avençado comprometeria o seu crédito para o futuro, pois o Estado não conseguiria contratar novos empréstimos, ou estes o seriam contratados sobre bases mais scveras, com outras garantias além das convencionais e em condições mais onerosas. ${ }^{57}$

Também Villegas ensina que "o empréstimo público é um contrato como todos os contratos qu' celebra o Estado, c' considerando que o Estado é um dos contratantes, não se pode objetar que o empréstimo é um contrato público" 58

Por sua vez, Jarach afirma ser comum qui o financiamento dos gastos públicos se faça por meio de "um contrato de empréstimo segundo as condições fixadas pelo Estado, na forma de oferta ao público de um contrato de adesão, com hase em uma lei sancionada pelo Parlamento" 59

Já Bielsa, ao tratar do empréstimo público, enfatiza que, "desde logo, trata-se de um contrato e não de um ato de autoridade, ainda que este contrato seja regido pelo direito público, como um contrato administrativo de indole financeira" 60

56. DE JUANO, Manuel. Curso de Finanzas y Derecho Tributurio. Rosario: Molachino. 1964. v. 3. p. 117.

57. Ibid., p. 117.

58. Op. cit., p. 356-357.

59. JARACH, Dino. Finanzas Publicas y Derecho Tributario. Buenos Aires: Cangallo, 1993. p. 886.

60. BIELSA. Rafacl. Compendio de Derecho Puiblico. Buenos Aires: Depalma. 1952. Derecho Fiscal, v. 3, p. 379 e ss. 
Dentre os doutrinadores pátrios também é prevalecente a idéia de que o empréstimo público é um contrato, ressaltando as opiniões clássicas de Baleeiro e Geraldo Ataliba, bem como a de outros com autoridade na matéria.

Para Baleeiro, "em sua forma pura e original, o crédito público se assenta em negócios juridicos do tipo contrato, quaisquer que sejam as peculiaridades desse ato quando dele participa contraente privilegiado e poderoso, como é o Estado" 61

A lição de Geraldo Ataliba assim se manifesta:

o empréstimo público, como gerador da divida pública, é um contrato pelo qual alguém transfere a uma pessoa pública, seja ela politica ou meramente administrativa, uma certa quantia de dinheiro, com a obrigação desta entregar igual quantia de dinheiro, com ou sem vantagens pecuniárias, no prazo convencionado. ${ }^{62}$

Ele prossegue dizendo que, uma vez qualificado como contrato, fica evidente o necessário pressuposto da liberdade de contratar, podendo ser o prestamista ou mutuante pessoa pública ou privada, e até mesmo pessoa de direito internacional.

Em seu entendimento, como o tomador do empréstimo seria uma pessoa submetida a regime jurídico de direito público, o contrato adquiriria feição especial, pois sua dinâmica e desempenho sofreriam as alterações decorrentes de exigências constantes dos princípios publicísticos. ${ }^{63}$

Outra opinião que se faz notar é a de Régis de Oliveira, que conceitua o empréstimo público como "contrato administrativo pelo qual o Estado recebe determinado valor que se obriga a pagar, na forma por ele estipulada" 64

Além disso, ele esclarece que:

61. Uma Introdução..., p. 432.

62. Empréstimos.... p. 05.

63. Ibid., p. 05 e ss.

64. Manual..., p. 152. 
o ato de autorização legislativa para contratação do empréstimo é um; o de concretização do empréstimo é outro. São dois atos juridicos autônomos. $O$ primeiro ingressa no mundo jurídico por meio de lei, ato produtor de efeitos jurídicos primários e de alteração da ordem normativa. Indiscutivel fruto da soberania do Estado, que não reconhece outro poder superior ao seu no âmbito internacional e também não conhece outro poder que lhe seja igual no âmbito interno. O segundo ato é o da contratação, ou seja, o da livre manifestação de vontade daqueles que vierem a adquirir os titulos emitidos pelo Estado ou simplesmente emprestar dinheiro, mediante algum tipo de garantia. ${ }^{65}$

Assim sendo, na sua opinião, o ato de emissão de autorização do empréstimo é que seria unilateral e fruto da soberania estatal. Já a contratação do empréstimo em si, realizada após a referida autorização legislativa, constituiria um ato bilateral, decorrente da vontade do contratante.

Também para Lobo Torres, a teoria que tem maior fundamento é a que considera os empréstimos públicos como contratos de direito administrativo, pois na sua visão eles assemelham-se às demais relações contratuais estabelecidas pelo Estado, uma vez que, como demonstrado por inúmeros juristas antigos e modernos, nestes contratos, "a Administração é dotada de poder de império, e jamais assume a posição de plena igualdade com o particular" 66

Já Celso Bastos apresenta uma opinião um pouco mais velada, dizendo que os empréstimos públicos são eminentemente voluntários, e que, em seu modo de ver, "resultam de um contrato de mútuo ou de aquisição de títulos representativos da divida, porém, estando sempre presente a espontaneidade" 67

65. Ibid., p. 154.

66. LOBO TORRES, Ricardo. Curso de Direito Financeiro e Tributário. 8. ed. Rio de Janeiro: Renovar, 2001. p. 196.

67. Op. cit., p. 60. 
Ainda no que toca à corrente contratualista. vale fazer referência ao entendimento singular do mestre italiano Bompani, pois ele afirma que:

a divida pública vem estipulada não pela força do exercício da autoridade financeira do Estado em relação aos cidadãos, mas em virtude de uma espontânea adesão dos particulares à oferla de mútuo passivo por parte do Estado, sendo os efeitos de tal contrato regulados pelo direito privado, salvo algum insuperável limite de direito público em caráter geral (grifos nossos), como por exemplo a impossibilidade de expropriação dos bens do domínio público estatal a fim de obter recursos para o pagamento dos juros da divida pública. ${ }^{68}$

\subsection{Conclusão.}

Como ficou demonstrado até o presente momento. a discussão em torno da natureza jurídica dos empréstimos públicos parece estar longe de alcançar um consenso doutrinário. Isso tendo em vista que apenas as duas principais correntes foram apresentadas, e ainda assim repletas de divergências nas argumentações dos seus partidários.

Entretanto. não nos furtaremos de emitir nossa opinião, já antecipando que a corrente contratualista, além de contar com um número maior de paladinos, contém argumentos que nos pareceram mais convincentes, do mesmo modo que a sua ramificação, no sentido de que esse contrato é um contrato de Direito Público, mostrouse mais persuasiva.

Inicialmente, para fins terminológicos, ressaltamos que alguns doutrinadores de Direito Administrativo fazem a distinção entre as expressões Contratos da Administração e Contratos Administrativos.

Segundo eles, a expressão "Contratos da Administração" deve ser empregada em sentido amplo, englobando tanto os contratos firmados pela

68. BOMPANI, Vito. Il Rapporto Giuridico di Debiro Pubblico. Bologna: Edizioni I niversitarit, 1947. p. $48-49$ 
Administração Pública, sob o regime de Direito Público, quanto sob o regime de Direito Privado. Por sua vez, o emprego da expressão "Contratos Administrativos" deve ser reservada para a designação apenas daqueles "ajustes que a Administração, nessa qualidade. celebra com pessoas físicas ou jurídicas, públicas ou privadas, para a consecução de fins públicos, segundo um regime jurídico de Direito Público" 69

Até porque, como leciona Meirelles:

embora tipica do direito privado, a instituição do cuntrato é utilizada pela Administração Pública na sua pureza originária (contratos privados reulizados pela Administração) ou com as udaptações necessárias aos negócios públicos (contratos administrativos propriamente ditos). Daí por que a teoria geral do contrato é a mesma tanto para os contratos privados (civis e comerciais) como para os contratos públicos, de que são espécies os contratos administrativos es acordos internacionais. ${ }^{70}$

Prossegue sua lição, dizendo que o verdadeiro critério de diferenciação dos contratos administrativos, dos demais contratos de direito privado celebrados pela Administração, seria a participação da Administração na relação jurídica com supremacia de poder para fixar as condições iniciais do ajuste. Isto é, a tipificação do contrato administrativo decorreria do privilégio administrativo na relação contratual, que faculta à Administração impor cláusulas exorbitantes e derrogatórias do direito privado, com a sua atuação sob a égide do Direito Público, ou seja, publicae utilitatis causa. $^{71}$

Ainda que admitamos essa supremacia do Estado-Administração em relação aos demais contratantes, a sua competência para a fixação das condições da contratação não deverá ser confundida com a expressão de um ato administrativo unilateral.

69. Cf. DI PIETR(), Maria Sylvia Zanella, op. cit. p. 207.

70. Op. cit. p. 194.

7!. Ibid. p. 196. 
Isso porque, os atos administrativos unilaterais, decorrentes do poder de império estatal, caracterizam-se pela existência de uma única declaração de vontade por parte do Estado-Administração, e pela sua imposição aos particulares, que deverão arcar com o ônus obrigacional dela advindo, independentemente de sua concordância e até mesmo contra a sua vontade.

Já no caso de um contrato administrativo, como acreditamos ser o contrato de empréstimo público, o fato de o Estado-Administração fixar unilateralmente as condições da contratação não lhe retira o caráter contratual, uma vez que o prestamista apenas se submeterá a tais condições se aceitá-las, ou seja, se concordar espontaneamente com elas. Portanto, não existe uma imposição decorrente do poder de império estatal, como no caso dos atos administrativos unilaterais, mas sim um acordo de vontades.

No dizer de Di Pietro, o contrato administrativo, ainda que as cláusulas regulamentares ou de serviço sejam fixadas unilateralmente, só vai ser aperfeiçoado se a outra parte consentir, uma vez que o contratado não é titular de mera faculdade outorgada pela Administração, mas assume direitos e obrigações junto ao poder público contratante. Falta às cláusulas fixadas unilateralmente pela Administração a imperatividade, que caracteriza os atos administrativos unilaterais, pois aquelas não têm, como estes últimos, a capacidade de impor obrigações ao particular, sem a sua manifestação de concordância.

Diz. ainda que o fato de a Administração estabelecer unilateralmente as condições do ajuste não lhe retiraria a natureza contratual, pois enquanto não se produzisse o acordo de vontades, nenhum efeito resultaria do ato unilateral da Administração. ${ }^{72}$

Conclui argumentando que no contrato administrativo existiria uma oferta feita a toda coletividade e, caso surgissem interessados que a aceitassem, teríamos então a celebração do ajuste, formando-se uma vontade contratual unitária. De modo que o contrato administrativo poderia ser enquadrado no conceito geral de contrato como um acordo de vontades gerador de direitos e obrigações recíprocos. ${ }^{73}$

Além disso, como frisou Ferreiro Lapatza, deve-se atentar para a tripartição funcional dos poderes estatais, pois as leis que, eventualmente. modifiquem

72. Op. cir., p. 210.

73. Ihid., p. $21 \mathrm{I}$. 
- contrato de empréstimo público interno, serão criadas pelo Estado-legilador. expressão de seu Poder Legislativo, enquanto o contrato em si é firmado pela EstadoAdministração, que é a expressão de seu Poder Executivo, de modo que não se pode dizer que é o próprio devedor (o Estado-Administração tomador do empréstimo) que modifica os efeitos do contrato por meio da lei. ${ }^{74}$

Observada essa divisão funcional, também resulta nos contratos de empréstimo público, como bem demonstrou Régis de Oliveira, a existência de dois atos jurídicos autônomos: o primeiro é o ato da autorização legislativa dada pelo Poder Legislativo (Estado-legislador) ao Poder Executivo (Estado-Administração) para a contratação do empréstimo; e o segundo é o ato da contratação propriamente dita, ou seja, da concretização do empréstimo, em que o Poder Executivo (EstadoAdministração) tem sua oferta de contrato aceita pelo prestamista.

De modo que apenas o primeiro ato é unilateral e decorrente da soberania do Estado, pois o Estado-legislador decide se a contratação será ou-não autorizada. Já o segundo ato, posterior à autorização legislativa concedida, é bilateral e fruto de um acordo das vontades do Estado-Administração (tomador do empréstimo) e do prestamista. ${ }^{75}$

Como disse Trotabas, em sua lição apresentada neste trabalho, a lei do empréstimo público é apenas a condição de exercício do poder de tomar emprestado, tendo em vista que o empréstimo não poderá se concretizar sem a intervenção do Poder Legislativo. Entretanto, o ato de tomar emprestado propriamente dito pertence ao Governo, como resultado de sua oferta de contrato feita pelo agente público competente, e aceita pelos prestamistas, consubstanciando, assim, o acordo de vontades que the imprime o caráter contratual. $^{76}$

No mais, a adesão dos prestamistas às clausulas fixadas unilateralmente pelo Estado-Administração também não exclui o caráter contratual, porque mesmo nos contratos entre particulares a idéia de livre discussão das cláusulas que o constituirão é, como asseverou Duverger. muito mais teórica do que prática, pois, na verdade, as

\footnotetext{
74. Op. cit., p. 551.

75. Manual..., p. 154.

76. Précis..., p. 391.
} 
partes quase sempre apresentam alguma desigualdade de fato, de modo que uma delas acaba impondo condiçõus de contratação. ${ }^{77}$

Quanto ao regime jurídico dos contratos de empréstimo público, consideramos que tais contratos sejam de Direito Público, não só pela presença do Fistado-Administração no pólo passivo da relação obrigacional, mas também pela existência, nessa espécie de contrato, de cláusulas especiais que privilegiam o ente público em nome do atendimento do interesse público. visto que a razão mesma da contratação do empréstimo é a consecução de uma finalidade pública, que deverá prevalecer ante qualquer interesse privado.

Assim sendo, legitimado estará o contrato de empréstimo público somente quando o ente público tomador do montante junto aos prestamistas agir como verdadeiro mandatário da sociedade, buscando mediante este contrato uma finalidade socialmente relevante, isto é, o bem da coletividade.

Tanto é assim que. em vista dessc objetivo de compromisso social, a presença em sua substância das chamadas cláusulas exorbitantes ou de prerrogativa, a favor do ente público e como expressão de seu poder de império. serão plenamente justificáveis e até mesmo desejáveis.

A lição de Régis de Oliveira é bastante enfática, no sentido de que é indubitável ser o empréstimo público um contrato de Direito Público, pelas seguintes razões que ele elencou:

a) para a contratação do empréstimo público deve haver prévia dotação orçannentária:

b) há a exigência de disposição legal específica;

c) deve existir também obrigatoriamente a autorização e controle do Poder Legislativo;

d) é necessária a finalidade pública;

e) se previsto em lei, há possibilidade de alteração unilateral de determinadas cláusulas:

f) há sujeição a prestação de contus;

g) apresentu-se inviável a execução forçada nos moldes do direito privado; 
h) poderá haver a rescisão unilateral do contrato, também chamado de resgate antecipado. $^{78}$

A presença de uma pessoa de Direito Público, como tomadora do empréstimo, submetida pois a um regime jurídico especial, dito público, imprime a esse contrato um aspecto peculiar, uma vez que a supremacia do interesse público sobre o interesse particular, bem como a indisponibilidade do interesse público, deverão ser respeitados, como princípios informadores que são do regime jurídico administrativo, tendo em vista que tal regime é o que resulta da caracterização normativa de determinados interesses atinentes à sociedade como um todo e não aos particulares. ${ }^{79}$

Como assevera Cirne Lima, "traço característico da Administração Pública, como forma de atividade. é estar vinculada, não a uma vontade ou a uma personalidade, porém a um fim impessoal [...] vinculada como se acha uo fim social" 80

A título conclusivo, consideramos o empréstimo público um contrato de Direito Público, pois é um contrato oferecido pelo ente público tomador, com base em seu crédito, tendo em vista uma finalidade pública, unilateralmente fixando as condições de restituição futura do capital, e que é aceito pelo prestamista, pessoa física ou juridica, pública ou privada, que dispõe do capital solicitado pelo primeiro.

São Paulo, novembro de 2004.

78. Manual..., p. 157.

79. Cf. BANDEIRA DE MELLO, Celso Antônio. Natureza e Regime Juridico das Autarquias. São Paulo: RT, 1968. p. 292.

80. CIRNE LIMA, Ruy. Principios de Direito Administrativo Rrasileiro. 2. ed. Porto Alegre: Do Globo. 1939. p. 52-53. 